\title{
EFFECT OF USING DIETARY ANTIBIOTIC AND ANISE OIL AS FEED ADDITIVES ON PERFORMANCE AND CARCASS QUALITY OF BROILER CHICKS
}

\author{
SAFA M.A. ELTAZI \\ Faculty of Agriculture, Omdurman Islamic University, P.O. Box 382, Sudan \\ E-Mail: $\underline{\text { safamohamedeltazi@yahoo.com }}$
}

\section{ABSTRACT}

Received at: 20/3/2014

The effect of feeding broiler chicks on diets containing antibiotic and different levels of anise oil as feed additive on productive performance, carcass characteristics and economical efficiency were studied. A total of two hundred and fifty one-day old, unsexed (Ross-308) broiler chicks were randomly divided

Accepted: 18/5/2014 into five experimental groups. Each group was further subdivided into five replicates ten chicks per pen in complete randomized design. The birds were fed with two basal diets (starter and finisher) to form five experimental groups. The first group (A) fed on basal diet without feed additives (negative control diet), the second group (B) fed on basal diet with $0.1 \%$ added antibiotic Neomycine sulphate (positive control diet). The other groups (C), (D) and (E) were fed on basal diet supplemented with anise oil (Pimpinella anisum) at levels (150, 250 and $400 \mathrm{ppm}$ ) respectively. The experimental diets were fed for 6-weeks duration. Health of the stock and performance parameters were recorded. At the end of the experiment, the birds were slaughtered, dressed then the different parameters and economical evaluation. The results showed that, the diet with 400ppm anise oil had significantly $(\mathrm{P}<0.05)$ heaviest body weight gain, highest feed intake, best feed conversion ratio, highest dressing percentage with highest percentages of commercial cuts (breast drumstick and thigh). In addition, the inclusion of anise oil in broiler diets showed significantly $(\mathrm{P}<0.05)$ the most tender breast and thigh meat and higher liver and gizzard percentages compared to both antibiotic and control diets. The birds fed the antibiotic and control diets produced significantly $(\mathrm{P}<0.05)$ highest abdominal fat percentage. The mortality rate did not significantly $(\mathrm{P}>0.05)$ affected by the experimental treatments. The highest profitability ratio (1.85) was recorded by the diet with 400ppm anise oil in broiler diet.

Keywords: Anise oil, Feed additives, broiler chicks.

\section{INTRODUCTION}

Pharmaceutical antibiotics feed additives have been used for more than 50 years to enhance growth performance and to prevent diseases in livestock feeding environments. However, the current trend to eliminate the use of antibiotics as growth promoters because of the residuals in meat products (Burgat, 1999) and development of antibiotic resistant bacteria population in human (Sahin et al., 2002).

Supplementation of natural components in poultry rations to improve production is widely adopted in the world. Recently aromatic plants and their associated essential oils or extracts are being concerned as potentially growth promoters. Anise (Pimpinella anisum L.), a member of the Apiaceae family, is an annual aromatic plant. The part of the plant used, is the fruit, in particular the seed and its essential oil.
Anise seed is listed by the Council of Europe as natural source of feed flavouring and in the USA it is considered as GRAS, i.e. Generally recognized as safe (Franz et al., 2005; Al-Beitawi et al., 2009). Anise has been examined for its antiparasitic and digestion stimulating properties (Cabuk et al., 2003), as well as its antibacterial (Tabanca et al., 2003), antifungal (Soliman and Badea, 2002), antipyretic (Afifi et al., 1994), antioxidant (Gulcin et al., 2003), antimicrobial (Al-Kassie., 2008), antihelmintic (Bhatti et al., 1996) and hypocholesterolemic (Craig, 1999) activities. Additionally, anise is reported to possess anticonvulsant (Pourgholam et al., 1999), antiepileptic (Janahmadi et al., 2008) and muscle relaxant (Albuquerque et al., 1995) properties. Some studies have been conducted to evaluate the use of anise seed or oil in poultry nutrition especially as growth promoters (Ciftci et al., 2005; Soltan et al., 2008; Al-Beitawi et al., 2009). 
The objective of this study was intended to gain more information about the effect of using dietary antibiotic and anise oil as feed additive on productive performance and carcass quality of broiler chicks.

\section{MATERIALS and METHODS}

A total of two hundred and fifty, one-day old unsexed (Ross-308) broiler chicks were randomly divided into 5 experimental groups of 50 chicks per group. Each group was further subdivided into 5 replicates at the rate 10 chicks per each. The chicks of each replicate were housed in a pen (1 square meter) in an opensided deep litter house. Anise oil (Pimpinella anisum) purchased from local market and then added to experimental diets. Then five experimental groups were used. The first group (A) fed on basal diet without feed additives (negative control diet), the second group (B) fed on basal diet with $0.1 \%$ added antibiotic Neomycine sulphate (positive control diet), the rest groups (C), (D) and (E) were fed on basal diet supplemented with anise oil at levels (150, 250 and $400 \mathrm{ppm})$ respectively. All the experimental diets were formulated to meet the nutrient requirements of broiler chicks according to (NRC, 1994) and composed from the local feed ingredients commonly used for poultry feeding in the Sudan. The experimental diets were fed for 6-weeks duration where two phases of feeding program involved in supplying starter (1-21 days of age) and finisher (2242 days of age). Calculated analysis of the experimental basal diets was done according to feedstuff analysis outlined by Ellis (1981), while determined chemical analysis was conducted by the AOAC (1995) methods. Formulation and proximate analysis and calculated analysis for the experimental basal diets are shown in Tables (1 and 2) respectively, while chemical composition of the super concentrate used in the basal diets is shown in Table (3). Feed and water were offered ad-libitum. The light was continuous throughout the experimental period. The performance of the experimental birds in term of feed intake, live weight gain and feed conversion ratio were recorded weekly. Health of the experimental stock and mortality rate were closely observed and recorded daily. At the end of $6^{\text {th }}$ week the experimental birds were individually weighed after overnight fast (except for water) then slaughtered without stunning. They were then scalded, manually plucked, washed and allowed to drain on wooden tables. Evisceration was performed by a ventral cut and visceral as well as thoracic organs were removed. After evisceration internal organs (heart, liver and gizzard) were removed, weighed individually and expressed as percentage of slaughtered weight. Eviscerated carcasses were weighed and then chilled in a refrigerator for 24 hours at $4^{\circ} \mathrm{C}$. Cold carcasses were recorded.

Table 1: Formulation and proximate analysis of the experimental basal diets (percent as fed).

\begin{tabular}{llcc}
\hline & Ingredients (\%) & Starter diet & Finisher diet \\
\hline A: & Formulation: & & \\
\hline & Grain sorghum & 51.00 & 63.00 \\
\hline & Wheat bran & 6.00 & 5.00 \\
\hline Groundnut meal & 15.00 & 13.00 \\
\hline Sesame meal & 16.00 & 7.00 \\
\hline Super concentrate & 5.00 & 5.00 \\
\hline Oyster shell & 2.75 & 2.75 \\
\hline Common salt & 0.25 & 0.25 \\
\hline Vegetable oil (corn) & 4.00 & 4.00 \\
\hline & Total & 100 & 100 \\
\hline & & \\
\hline & Determined analysis & 96.40 & 94.00 \\
\hline Dry matter & 23.00 & 21.69 \\
\hline Crude protein (N\% x 6.25) & 6.73 & 6.80 \\
\hline Ether extract & 6.20 & 5.00 \\
\hline Crude fibre & 9.94 & 7.86 \\
\hline Ash & 50.53 & 53.65 \\
\hline Nitrogen free-extract & & \\
\hline & & \\
\hline
\end{tabular}


Table 2: Calculated analysis of the experimental diets dry matter basis (DM).

\begin{tabular}{|c|c|c|}
\hline Item & Starter diet & Finisher diet \\
\hline Metabolizable energy (Kcal/kg) & 3051 & 3138 \\
\hline Crude fat & 9.86 & 8.33 \\
\hline Crude protein & 23.12 & 20.09 \\
\hline Lysine & 1.14 & 1.05 \\
\hline Methionine & 0.52 & 0.43 \\
\hline Cystine & 0.33 & 0.27 \\
\hline Methionine + cystine & 0.87 & 0.71 \\
\hline Calcium & 1.10 & 0.93 \\
\hline Available phosphorus & 0.61 & 0.54 \\
\hline Caloric-protein ratio & 132 & 156 \\
\hline ME Kcal $/ \mathrm{kg}$ : protein $\%$ & & \\
\hline
\end{tabular}

Metabolizable energy: calculated according to Ellis (1981)

Table 3: Chemical composition of the super concentrate used in the basal diets formulation (Hendrix broiler concentrate).

\begin{tabular}{llc}
\hline Metabolizable energy & & $1900(\mathrm{Kcal} / \mathrm{kg})$ \\
\hline Crude protein & & $32.00 \%$ \\
\hline & Lysine & $11.00 \%$ \\
\hline & Methionine & $2.80 \%$ \\
\hline Calcium & Methionine + cystine & $2.25 \%$ \\
\hline Available phosphorus & & $8.00 \%$ \\
\hline
\end{tabular}

All the slaughtered birds were used for dissection. The breast, thigh and drumstick of the left side of each carcass were dislocated, weighed and expressed as percentage of cold carcass weight. Taste panel was done for broiler's breast and thigh meat after wrapped individually in aluminum foil, and roasted in an electric oven at $175^{\circ} \mathrm{C}$ for 90 minutes. Ten taste panelists were used to score colour, flavour, tenderness and juiciness of the meat, according to the guidelines of Cross et al. (1978). Statistical analyses were made by analysis of variance for a completely randomized design, according to Steel and Torrie (1986).

\section{RESULTS}

The effect of feeding different levels of anise oil on broiler's performance is shown in Table (4). Final body weight, body weight gain, total feed intake and feed conversion ratio were significantly $(\mathrm{P}<0.05)$ affected by the addition of anise oil to broiler diets. The highest body weight and body weight gain were significantly $(\mathrm{P}<0.05)$ recorded by the diet with $400 \mathrm{ppm}$ anise oil compared to both positive and negative control diets. The diets with 150 and 250 ppm recorded significantly $(\mathrm{P}<0.05)$ lower body weight and body weight gain compared to positive control diet.

The treatment effect on the feed intake was significantly $(\mathrm{P}<0.05)$ affected by the inclusion of anise oil in broiler diets. The diet with 400ppm showed significantly $(\mathrm{P}<0.05)$ the highest feed intake compared to other experimental diets. The diets with 150 and $250 \mathrm{ppm}$ anise oil consumed significantly $(\mathrm{P}<0.05)$ lowest feed intake compared to positive control diet. The diet with $400 \mathrm{ppm}$ anise oil recorded significantly $(\mathrm{P}<0.05)$ better feed conversion ratio compared to other experimental diets. The differences between the diets with 150 and $250 \mathrm{ppm}$ anise oil and the positive control diet were insignificant $(\mathrm{P}>0.05)$. All the chicks were apparently healthy and the mortality was not significantly affected by the experimental treatments. 
Assiut Vet. Med. J. Vol. 60 No. 142 July 2014

Table 4: The effect of feeding different level of anise oil on performance of broiler chicks (1-42 days).

\begin{tabular}{lcccccc}
\hline \multicolumn{1}{c}{ Parameter } & $\mathrm{A}$ & $\mathrm{B}$ & $\mathrm{C}$ & $\mathrm{D}$ & $\mathrm{E}$ & $\mathrm{SEM}$ \\
\hline Initial body weight (g/chick) & 45.10 & 45.32 & 45.21 & 45.20 & 45.32 & - \\
\hline Final body weight (g/chick) & $1742.00^{\mathrm{d}}$ & $1982.33^{\mathrm{b}}$ & $1873.00^{\mathrm{c}}$ & $1891.55^{\mathrm{c}}$ & $2150.30^{\mathrm{a}}$ & 9.85 \\
\hline Body weigh gain (g/chick) & $1696.90^{\mathrm{d}}$ & $1937.01^{\mathrm{b}}$ & $1827.79^{\mathrm{c}}$ & $1846.35^{\mathrm{c}}$ & $2104.98^{\mathrm{a}}$ & 9.72 \\
\hline Total feed intake (g/chick) & $3478.64^{\mathrm{d}}$ & $3719.06^{\mathrm{b}}$ & $3491.07^{\mathrm{c}}$ & $3544.99^{\mathrm{c}}$ & $3852.11^{\mathrm{a}}$ & 8.93 \\
\hline Feed conversion ratio & $2.05^{\mathrm{a}}$ & $1.92^{\mathrm{b}}$ & $1.91^{\mathrm{b}}$ & $1.92^{\mathrm{b}}$ & $1.83^{\mathrm{c}}$ & 0.007 \\
\hline Mortality \% & 0.001 & 0.00 & 0.00 & 0.00 & 0.00 & $0.001^{\mathrm{NS}}$ \\
\hline
\end{tabular}

A: Negative control diet (without feed additives)

B: Positive control diet ( $0.1 \%$ antibiotic Neomycine sulphate)

C: 150 ppm anise oil

D: $250 \mathrm{ppm}$ anise oil

E: 400 ppm anise oil

N.S. Not statistically significant $(\mathrm{P}>0.05)$

SEM: Standard error of the means

Means on the same raw with the same superscripts are not significantly different $(\mathrm{P}>0.05)$.

Table (5) shows the effect of feeding different levels of anise oil on carcass characteristic of the broilers. All the measured parameters were significantly $(\mathrm{P}<0.05)$ affected by the experimental treatments. The diet with $400 \mathrm{ppm}$ anise oil gave significantly $(\mathrm{P}<0.05)$ highest hot and cold dressing percentages and highest commercial cuts percentages (breast, drumstick and thigh) compared to other experimental diets. Also the differences between diets 150 and $250 \mathrm{ppm}$ anise oil and positive control diet were insignificant $(\mathrm{P}>0.05)$ for all these values.

Table 5: Means values for the dressing carcass percentages and commercial cut of broiler carcasses.

\begin{tabular}{lcccccc}
\hline \multicolumn{1}{c}{ Parameter } & A & B & C & D & E & SEM \\
\hline Hot dressing percentage & $67.50^{\mathrm{c}}$ & $68.82^{\mathrm{b}}$ & $68.73^{\mathrm{b}}$ & $68.82^{\mathrm{b}}$ & $69.13^{\mathrm{a}}$ & 0.17 \\
\hline Cold dressing percentage & $67.01^{\mathrm{c}}$ & $68.80^{\mathrm{b}}$ & $68.52^{\mathrm{b}}$ & $68.72^{\mathrm{b}}$ & $69.83^{\mathrm{a}}$ & 1.13 \\
\hline Breast as \% of old carcass & $24.62^{\mathrm{c}}$ & $25.75^{\mathrm{b}}$ & $25.03^{\mathrm{b}}$ & $25.52^{\mathrm{b}}$ & $26.50^{\mathrm{a}}$ & 1.20 \\
\hline Drumstick as \% of cold carcass & $14.82^{\mathrm{c}}$ & $15.63^{\mathrm{b}}$ & $15.69^{\mathrm{b}}$ & $15.72^{\mathrm{b}}$ & $16.25^{\mathrm{a}}$ & 0.2 \\
\hline Thigh as \% of cold carcass & $15.01^{\mathrm{c}}$ & $15.80^{\mathrm{b}}$ & $15.83^{\mathrm{b}}$ & $15.92^{\mathrm{b}}$ & $16.82^{\mathrm{a}}$ & 0.22 \\
\hline
\end{tabular}

Table (6) shows the effect of feeding different levels of anise oil on abdominal fat and giblets (liver, heart and gizzard) as percentage of body weight. All the measured parameters were significant $(\mathrm{P}<0.05)$ except the heart percentage. The addition of anise oil to broiler diets significantly decreased the abdominal fat percentage and increased the liver and gizzard percentages compared to both positive and negative control diets.

Table 6: Body weight and organ proportions of broiler chickens.

\begin{tabular}{lcccccc}
\hline \multicolumn{1}{c}{ Parameter } & $\mathrm{A}$ & $\mathrm{B}$ & $\mathrm{C}$ & & $\mathrm{D}$ & SEM \\
\hline Final body weight (g/chick) & $1742.00^{\mathrm{D}}$ & $1982.33^{\mathrm{b}}$ & $1873.00^{\mathrm{c}}$ & $18.91 .55^{\mathrm{c}}$ & $2150.30^{\mathrm{a}}$ & 9.85 \\
\hline Abdominal fat as \% of body weight & $2.42^{\mathrm{a}}$ & $2.41^{\mathrm{a}}$ & $1.92^{\mathrm{b}}$ & $1.92^{\mathrm{b}}$ & $1.91^{\mathrm{b}}$ & 0.017 \\
\hline Liver as \% of body weight & $2.10^{\mathrm{b}}$ & $2.11^{\mathrm{b}}$ & $2.50^{\mathrm{a}}$ & $2.50^{\mathrm{a}}$ & $2.63^{\mathrm{a}}$ & 0.11 \\
\hline Heart as \% of body weight & 0.5 & 0.5 & 0.5 & 0.5 & 0.5 & $0.013^{\mathrm{NS}}$ \\
\hline Gizzard as \% of body weight & $2.00^{\mathrm{b}}$ & $2.05^{\mathrm{b}}$ & $2.52^{\mathrm{a}}$ & $2.55^{\mathrm{a}}$ & $2.63^{\mathrm{a}}$ & 0.12 \\
\hline
\end{tabular}


Table (7) shows the effect of dietary treatment on subjective scores for breast and thigh of boiler meat. All the values (juiciness, flavour and colour) did not differ significantly ( $\mathrm{P}>0.05)$ among the dietary treatments except the tenderness of the breast and thigh meat of broiler. The addition of anise oil to broiler diets showed significantly $(\mathrm{P}<0.05)$ the highest tenderness score for both the breast and the thigh meat compared to both positive and negative control diets.

Table 7: Subjective scores for the breast and thigh of broiler meat.

\begin{tabular}{lllllll}
\hline \multicolumn{1}{c}{ Parameters } & A & B & C & D & E & SEM \\
\hline Tenderness & & & & & & \\
\hline Thigh & $5.61^{\mathrm{b}}$ & $5.62^{\mathrm{b}}$ & $6.72^{\mathrm{a}}$ & $6.75^{\mathrm{a}}$ & $6.85^{\mathrm{a}}$ & 0.03 \\
\hline Breast & $5.50^{\mathrm{b}}$ & $5.53^{\mathrm{b}}$ & $6.62^{\mathrm{a}}$ & $6.65^{\mathrm{a}}$ & $6.77^{\mathrm{a}}$ & 1.02 \\
\hline Juiciness & & & & & & \\
\hline Thigh & 5.53 & 5.53 & 5.62 & 5.50 & 5.70 & $0.03^{\mathrm{NS}}$ \\
\hline Breast & 5.42 & 5.45 & 5.59 & 5.48 & 5.63 & $0.02^{\mathrm{NS}}$ \\
\hline Flavour & & & & & & \\
\hline Thigh & 5.32 & 5.50 & 5.46 & 5.39 & 5.40 & $0.02^{\mathrm{NS}}$ \\
\hline Breast & 5.46 & 5.37 & 5.39 & 5.45 & 5.51 & $0.01^{\mathrm{NS}}$ \\
\hline Colour & & & & & & \\
\hline Thigh & 5.28 & 5.23 & 5.21 & 5.32 & 5.41 & $0.03^{\mathrm{NS}}$ \\
\hline Breast & 5.31 & 5.37 & 5.22 & 5.41 & 5.50 & $0.02^{\mathrm{NS}}$ \\
\hline
\end{tabular}

Table (8) shows calculation of total cost, revenues and net profit for the experimental groups. The results obtained from the economic study indicated that, group (E) with $400 \mathrm{ppm}$ anise oil showed the highest profitability ratio (1.85) compared to the negative control group.

Table 8: Total cost, revenues and net profit of broiler chicks fed on different levels of anise oil.

\begin{tabular}{llccccc}
\hline & \multicolumn{1}{c}{ Item } & A & B & C & D & E \\
\hline Cost(SDG) & & & & & \\
\hline & Chick purchase & 6.00 & 6.00 & 6.00 & 6.00 & 6.00 \\
\hline & Management & 4.00 & 4.00 & 4.00 & 4.00 & 4.00 \\
\hline & Feed & 11.70 & 12.70 & 11.72 & 11.79 & 12.00 \\
\hline & Total cost(SDG) & 21.70 & 22.70 & 21.72 & 21.79 & 22.00 \\
\hline Revenues & Average eviscerated carcass weight $(\mathrm{kg})$ & 1.17 & 1.36 & 1.29 & 1.30 & 1.49 \\
\hline & Trice (SDG/kg) & 23.00 & 23.00 & 23.00 & 23.00 & 23.00 \\
\hline & 26.91 & 31.28 & 29.67 & 29.90 & 34.27 \\
\hline & Total revenues & & & & & \\
\hline Net profit & Total revenues & 26.91 & 31.28 & 29.67 & 29.90 & 34.27 \\
\hline & Total cost & 21.70 & 22.70 & 21.72 & 21.79 & 22.00 \\
\hline & Net profit/bird & 5.21 & 8.58 & 7.95 & 8.11 & 12.27 \\
\hline & Net profit/kg meat & 4.45 & 6.30 & 6.16 & 6.24 & 8.23 \\
\hline & Profitability ratio/kg meat & 1.00 & 1.41 & 1.38 & 1.40 & 1.85 \\
\hline
\end{tabular}

\section{DISCUSSION}

The effect of feeding different levels of anise oil on the productive performance of broiler chicks is shown in Table (4). The highest body weight and body weight gain were significantly $(\mathrm{P}<0.05)$ recorded by the diet with 400ppm anise oil compared to both positive and negative control diets. The improvement in body weight gain may be related to active ingredient found in the anise oil such as anethol which has stimulating effect on digestive system and increases production of digestive enzymes that improved utilization of digestive products through enhanced liver function (Cabuk et al., 2003; Hernandez et al., 2004 and Osman et al., 2005). This result agreed with the findings of Abu-Egla et al. (2001); El-Ghammary et al. (2002) and Hassan et al. (2004) who found that, the increase in live body weight and body weight gain may be due to the different active ingredients, particularly anethol and 
eugenol in anise which have digestive stimulating effects. Similarly, Simsek et al. (2007) stated that, the improved body weight in the diet supplemented with $400 \mathrm{ppm}$ of anise oil could be due to positive effects of anise oil on digestive system. In addition, Hernandez et al. (2004) reported that supplementation of essential oil extract from oregano, cinnamon and pepper improved apparent whole tract and ileac digestibility of the nutrients in broilers. The result was in line with the findings of Jang et al. (2004) who showed that supplementation of a blend of commercial essential oils combined with lactic acid increased trypsin and pancreatic amylase activity in broiler. The results coincided with the finding of Ertas et al. (2005) reported that the addition of essential oils mix (oregano, clove and anise) in the diet improved body weight of broilers. In addition, positive effects of dietary essential oils on bodyweight were observed by Alcicek et al. (2003) and Denli et al. (2004). Moreover, Jamroz et al. (2003) found that the inclusion of 150 or $300 \mathrm{mg} / \mathrm{kg}$ of a plant extract containing capsaicin, carvacrol and cinnamicaldehyde in the diet improved body weight by 5.4 and $8.1 \%$, respectively. In contrast, Botsoglou et al. (2004) reported that the supplementation of essential oils to a diet had no beneficial effect on body weight. Similar result was observed by Jamroz et al. (2005) who noted that a plant extract included in a broiler diet did not improve the body weight. The diets with 150 and 250 ppm anise oil showed significantly $(\mathrm{P}<0.05)$ lower body weight and body weight gain compared to the positive control diet.

The diet with 400 ppm anise oil showed significantly $(\mathrm{P}<0.05)$ the highest feed intake compared to the other experimental diets. This improvement in feed intake may be attributed to the appetizing effect of active ingredient, such as anethol in anise (Cabuk et al., 2003). Similar result was obtained by Ertas et al. (2005) who reported that the addition of essential oils mix (oregano, clove and anise) in the diet improved feed intake by broilers. In contrast, Lee et al. (2003); Botsoglou et al. (2004) and Hernandez et al. (2004) reported that addition of plant extracts or essential oils to the diet had no beneficial effect on feed intake.

The diet with 400ppm anise oil produced significantly $(\mathrm{P}<0.05)$ better feed conversion ratio compared to the other experimental diets, and the difference between the diets with 150 and $250 \mathrm{ppm}$ anise oil and the positive control diet were insignificant $(\mathrm{P}>0.05)$. The improvement in feed conversion ratio in the diet with 400ppm could be related to the digestive stimulating effect of anise (Cabuk et al., 2003), particularly the digestion of protein, fat and cellulose (Jamroz and Kamel, 2002). In addition, several researchers reported that anise oil significantly improved the feed conversion ratio of broiler chickens (Ather, 2000; Williams and Losa, 2001; Giannenas et al., 2003;
Ciftci et al., 2005). The positive effect of anise oil in broiler diets on the final body weight, body weight gain and feed conversion ratio can be explained by the fact that, anise have medical properties such as antimicrobial effect (Tabanca et al., 2003) and antifungal effect (Soliman and Badea, 2002) which improved the over all productive performance of broiler chicks. In contrast, Lee et al. (2003); Botsoglou et al. (2004) and Hernandez et al. (2004) reported that addition of plant extracts or essential oils to the diet had no beneficial effect on feed conversion ration.

As shown in Table (5) the hot and cold dressing percentages were significantly $(\mathrm{P}<0.05)$ improved by the addition of anise oil to the diets of broiler compared to negative control diet. The highest hot and cold dressing percentages were significantly $(\mathrm{P}<0.05)$ recorded by the diet with $400 \mathrm{ppm}$ anise oil. These results may be attributed to the coincided effect of these levels in feed intake and weight gain. These results agreed with Simsek et al. (2007) who found that, there were significantly $(\mathrm{P}<0.05)$ improvement in hot and cold carcass yield for the diet that supplemented with $400 \mathrm{ppm}$ of anise oil compared to control diet. Similarly, Hamodi and Al-Khalani (2011) mentioned that, the dressing of the diet that contain $6 \mathrm{~kg} / \mathrm{ton}$ anise seeds was significantly $(\mathrm{P}<0.05)$ increased compared to control diet. In addition, Alcicek et al. (2003) reported that, adding essential oil (Herbomix ${ }^{\mathrm{TM}}$ ) in the ration had positive effects on the carcass yield in broilers.

The percentages of commercial cuts (breast, drumstick and thigh) showed significantly $(\mathrm{P}<0.05)$ improvement with the inclusion of anise oil in broiler diets compared to negative control diet. The highest commercial cuts percentages (breast, drumstick and thigh) were significantly $(\mathrm{P}<0.05)$ observed by the diet with $400 \mathrm{ppm}$ anise oil. This improvement may be resulted from positive effects of the anise oil on carcass performance. These results partially agreed with Hamodi and al-Khalani (2011) who found significant $(\mathrm{P}<0.05)$ increase in carcass cuts (breast and thigh) when broiler diet was supplemented with anise seed or karkade flower.

As shown in Table (6) the inclusion of anise oil in broiler diets significantly $(\mathrm{P}<0.05)$ affected the percentages of abdominal fat and giblets (liver and gizzard) except the heart percentage. The diets supplemented with anise oil significantly $(\mathrm{P}<0.05)$ showed the highest liver and gizzard percentages compared to both positive and negative control diets. This may be related to the effects of anethol on the digestive system and liver metabolism. Similar results were recorded by Simsek et al. (2007) who found that, there were significant $(\mathrm{P}<0.05)$ improvement in liver and gizzard percentages for the diets that supplemented with anise oil compared to control diet. 
Moreover, Hamodi and Al-Khalani (2011) stated that, addition of anise seeds (6 kg/ton feed) significantly $(\mathrm{P}<0.05)$ increased the liver percentage of broiler chickens. On the other hand, inclusion of anise oil in broiler diets significantly $(\mathrm{P}<0.05)$ decreased the abdominal fat percentage compared to both negative and positive control diets. Similar result was obtained by Hamodi and el-Khalani (2011) who reported that, supplementing anise seeds at level $6 \mathrm{~kg} /$ ton feed significantly $(\mathrm{P}<0.05)$ decreased the abdominal fat percentage compared to control group. Also, Ashan (2011) found that, the lowest percentage of abdominal fat was recorded by the diet supplemented by 200 ppm anise oil compared to other experimental diet (control, 200 ppm senna and 200 pm mixture of senna and anise oils).

As shown in Table (7) no significant differences were observed between all treatments groups in subjective meat quality attributed (colour, flavour and juiciness) except for tenderness of the breast and thigh meat, all scores being at above moderate values. The addition of anise oil to broiler diets recorded significantly $(\mathrm{P}<0.05)$ the most tender breast and thigh meat compared to both negative and positive control diets. This effect could be explained by the sedative and aromatic characteristics of the active items of anise oil (Cakmakci and Celik, 2004). One of the most active item anethol has sedative effects which reduces the movements of animals, thus more body weight gain and tenderness of meat for birds fed on anise oil that may result from the limited activity of broilers. As shown in Table (8), the economic evaluation of the experimental diets indicated that the diet supplemented with $400 \mathrm{ppm}$ anise oil showed the highest profitability ratio (1.8). This might be related to the higher return of the weight gains recorded by this group of chicks compared to other experimental groups.

In conclusion, the supplementation of anise oil to broiler diet at $400 \mathrm{ppm}$ enhanced growth, reproductive performance and organoletpic characteristics of meat. This supplement can completely replace antibiotic Neomycine sulphate without having any adverse effect on performance and carcass quality of broiler chicks.

\section{REFERENCES}

Abu-Egla, E.; Genedy, S.G.K.; Abou-Zeid, A.E. and Zewil, H.S. (2001): Nigella sative seeds oil meal as non-traditional source of plant protein in Japanese quail diets. Egyptian Poultry Science (21): 107-125.

Afifi, N.A.; Ramadan, A.; El-Kashoury, E.A. and ElBanna, H.A. (1994): Some pharmacological activities of essential oils of certain umbelliferous fruits. Vet. Med. J. Giza 42: 85-92.
Al-Beitawi, N.A.; El-Ghousein, S.S. and Abdullah, H.M. (2009): Antibiotic growth promoters and anise seeds in broiler diets. Jordan J. Agric. Sci., 5: 472-481.

Albuquerque, A.A.; Sorenson, A.L. and Leal-Cardoso, J.H. (1995): Effects of essential oil of crotonzehntneri and of anethol and estragole on skeletal muscles. J. Ethnopharmacology, 49: 41-49.

Alcicek, A.; Bozkurt, M. and Cabuk, M. (2003): The effect of an essential oil combination derived from selected herbs growing wild in Turkey on broiler performance. S. Afr. J. Anim. Sci., 33: 89-94.

Al-Kassie, G.A.M. (2008): The effect of anise and rosemary on broiler performance. Int. J. Poult. Sci., 7: 243-245.

$A O A C$ (1995): Official methods of analytical $\left(13^{\text {th }}\right.$ ed). Association of Official analytical Chemists, Washington, D.C., USA.

Ashan, S.K. (2011): Effect of herbal oil on performance, carcass quality, blood parameters and immune system in female broiler chicken. Available online at www.scholarsresearchlibrary.com.

Ather, M.A.M. (2000): Polyherbal additive proves effective against vertical transmission of IBD. World Poultry Elsevier, 16: 50-52.

Bhatti, M.A.; Khan, M.T.J.; Ahmed, B.; Jamshaid, M. and Ahmad, W. (1996): Antibacterial activity of anise seed (Pimpinella anisum). Fitoterapia, 67: 372-374.

Botsoglou, N.A.; Christaki, E.; Elorou-Paneri, P.; Giannenas, I.; Papageorgiou, G. and Spais, A.B. (2004): The effect of a mixture of herbal essential oils or a-tocophery $\mathrm{L}$ acetate on performance parameters and oxidation of body lipid in broilers. S. Afr. J. anim. Sci., 34:52-61.

Burgat, V. (1999): Residues of drugs of veterinary use in food. Rev. Part., 41: 985-990.

Cabuk, M.; Alcicek, A.; Bozkurt, M. and Imre, N. (2003): Antimicrobial properties of the essential oils isolated from aromatic plants and using possibility as alternative feed additives. II National animal Nutrition Congress, 18-20 September, pp. 184-187.

Cakmakci, S. and Celik, I. (2004): Gida katki maddeleri. Atatirk Univ. Ziraat Fak. Ders Yaynlari, 164-165.

Ciftci, M.; Guler, T.; Dalkilic, B. and Nihat, Ertas, $O$. (2005): The effect of anise oil (Pimpinella anisum) on broiler performance. Int. J. Poult. Sci., 4: 851-855.

Craig, W.J. (1999): Health-promoting properties of common herbs. Am. J. chin. Nutri, 70 (suppl.), 491-499.

Cross, H.R.; Moen, R. and Stanfield, M.S. (1978): Training and testing of judges for sensory analysis of meat quality. Food Technology, 32-48. 
Denli, M.; Okan, F. and Uluocak, A.M. (2004): Effect of dietary supplementation of herb essential oils on the growth performance, carcass and intestinal characteristics of quail (coturnix coturnix japonica) S Afr. J. anim. Sci., 34: 174-179.

El-Ghammary, A.A.; El-Mallah, G.M. and El-Yamny, A.T. (2002): The effect of incorporation yeast culture, Nigella sativa seeds and fresh garlic in broiler diets on their performance. Egyptian Poultry Science, (22): 445-459.

Ellis, N. (1981): The nutrient composition of Sudanese animal feed. Bulletin 1: Northern and Central Sudan, Central Animal Nutrition Research Laboratory, Kuku Research Centre, Khartoum North, Sudan.

Ertas, O.N.; Guler, T.; Ciftci, M.; Dalkilic, B. and Simsek, G. (2005): The effect of essential oil mix derived from oregano, clove and anise on broiler performance. Int. J. Poult. Sci. 4 (11): 879-884.

Franz, C.; Bauer, R.; Carle, R.; Tedesco, D.; Tubaro, A. and Zitteri-Eglseer, K. (2005): Study of the assessment of plant/herb extracts and their naturally or synthetically produced components as "additives" for use in animal production (CFT/EFSA/FEEDAP/2005/01).

Giannenas, I.; Florou-Paneri, P.; Papazahariadou, M.; Christaki, E.; Botsoglou, N.A. and Spais, A.B. (2003): Effect of dietary supplementation with oregano essential oil on performance of broilers after experimental infection with Eimeria tenella. Archive Tierernährung, (57): 99-106.

Gulcin, I.; Oktay, M.; Kirecci, E. and Irfan Kufrevioglu, O. (2003): Screening of antioxidant and antimicrobial activities of anise (Pimpinella anisum L.) seed extract. Food Chem., 83: 371-382.

Hamodi, S.J. and Al-Khalani, F.M. (2011): Compared between anise seeds (Pimpinella anisum L.) and Roselle flowers (Hibiscus abdariffa) by their affected on production performance of broiler. Advances in Environmental Biology, 5(2): 461-464.

Hassan, I.I.; Askar, A.; Gehan, A. and El-Shourbagy, A. (2004): Influence of some medicinal plants on performance, physiological and meat quality traits of broiler chicks. Egyptian Poultry Science, (24): 247-266.

Hernandez, F.; Madrid, J.; Garcia, V.; Orengo, J. and Megias, M.D. (2004): Influence of two plants extract on broiler performance digestibility and digestive organ size. Poultry Sci., 83: 169-174.

Jamroz, D. and Kamel, C. (2002): Plant extracts enhance broiler performanc In non-ruminant nutrition: Antimicrobial agents and plant extracts on immunity, health and performance. Journal Animal Science, 80 (E. Suppl. 1): 41.
Jamroz, D.; Orda, J.; Kamel, C.; Wiliczkiewicz, A.; Wertelecki, T. and Skorupinska, J. (2003): The influence of phytogenetic extracts on performance, nutrient digesti-bility, carcass characteristics, and gut microbial status in broiler chickens. J. Anim. Feed Sci., 12: 583-596.

Jamorz, D.: Wiliczkiewicz, A.; Wertelecki, T.; Orda, $J$. and Sukorupinska, J. (2005): Use of active substances of plant origin in chicken diets based on maize and locally grown cereals. $\mathrm{Br}$. Poult. Sci., 46: 485-493.

Janahmadi, M.; Farajnia, S.; Vatanparast, J.; Abbasipour, H. and Kamalinejad, M. (2008): The fruit essential oil of Pimpinella anisum L. (umbelliferae) induces neuronal hyperexcitability in snail partly through attenuation of after-hyperpolarization. J. Ethnopharmacol., 120: 360-365.

Jang, I.S.; Ko, Y.H.; Yang, H.Y.; Ha, J.S.; Kim, J.Y.; Kang, S.Y.; Yoo, D.H.; Nam, D.S.; Kim, D.H. and Lee, CY. (2004): Influence of essential oil components on growth performance and the functional activity of the pancreases and small intestine in broiler chickens. Asian Aust. J. anim. Sci., 17: 394-400.

Lee, K.W.; Everest, H.; Kappert, H.J.; Yeom, K.H. and Beynen, A.C. (2003): Dietary carvacrol lowers body weight gain but improves feed conversion in female broiler chickens. Appli. Poult. Res., 12: 394-399

NRC (National Research Council) (1994): Nutrient requirement of poultry $9^{\text {th }}$ Rev. ed National Academy Press, Washington, DC.

Osman, N.E.; Talat, G.; Mehmet, C.; Bestami, D. and Simsek, U.G. (2005): The effect of an essential oil mix derived from oregano, clove and anise on broiler performance. Int. J. Poult. Sci., 4: 879-884.

Pourgholam, M.H.; Majzoob, S.; Javadi, M.; Kamalinejad, M.; Fanaee, G.H. and Sayyah, M. (1999): The fruit essential oil of Pimpinella anisum exerts anticonvulsant effect in mice. J. Ethnopharmacol., 66: 211-215.

Sahin, O.; Morishita, T.Y. and Zhang, Q. (2002): Campylobacter colonization in poultry: Source of infection modes and transmission on anim. Health Res. Rev., 3: 95-105.

Simsek, U.G.M.; Ciftci, T. and Guler, Ertas, O.N. (2007): The effect of dietary antibiotic and anise oil supplementation on body weight, carcass characteristics and organoleptic analysis of meat in broiler. Revue. Med. Vet. 158(10): 514-518.

Soliman, K.M. and Badea, R.I. (2002): Effect of oil extracted from some medicinal plants on different mycotoxigenic fungi. Food Chem. Toxicol., 40: 1669-1675.

Soltan, M.A.; Shewita, R.S. and El-Katcha, M.I. (2008): Effect of dietary anise seeds 
supplementation on growth performance, immune response, carcass traits and some blood parameters of broiler chickens. Int. J. Poult. Sci., 7: 1078-1088.

Steel, R.G.D. and Torrie, J.H. (1986): Principles and procedures of statistics. A Biometrical Approach ( $2^{\text {nd }}$ ed). McGraw Hill Book Company, Ins. NY, USA.
Tabanca, N.; Bedir, E.; Kirimer, N.; Baser, K.H.; Khan, S.I.; Jacob, M.R. and Khan, I.A. (2003): Antimicrobial compounds from Pimpinella species growing in Turkey. Planta Medical, 69: 933-938.

Williams, P. and Losa, R. (2001): The use of essential oils and their compounds in poultry nutrition. World Poultry - Elsevier, (17): 14-15.

\title{
أثر استخدام المضاد الحيوي وزيت اليانسون كإضافة علفية على الأداء وخصائص الأبيح في الاجاج الاحم
}

\author{
صفاء محمد عبد الوهاب التازى
}

E-Mail: $\underline{\text { safamohamedeltazi@yahoo.com. }}$

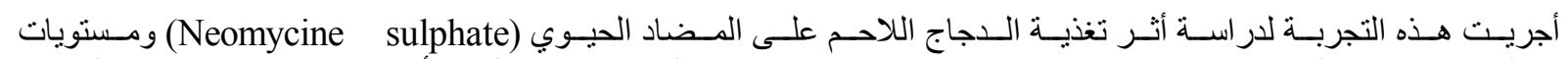

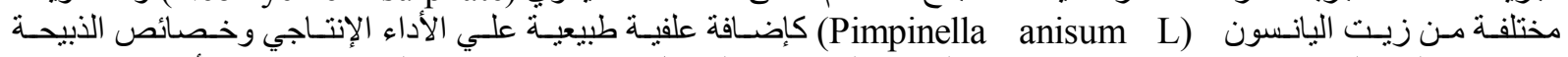

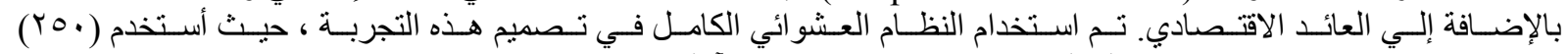

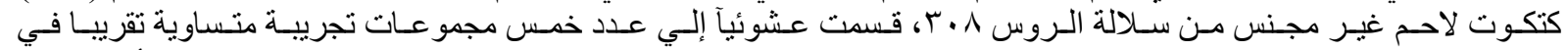

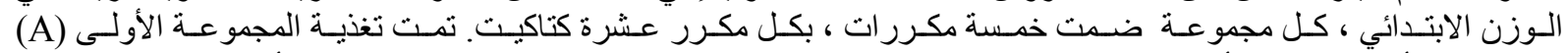

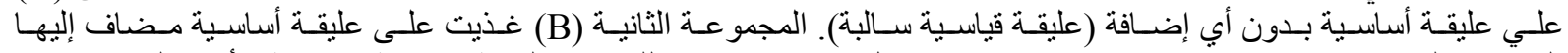

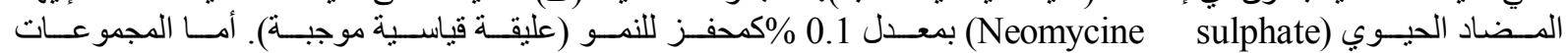

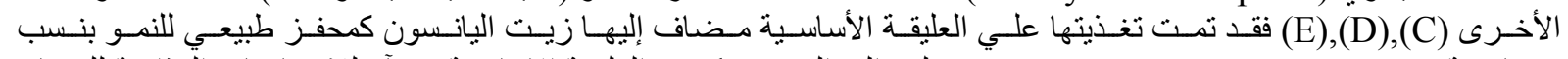

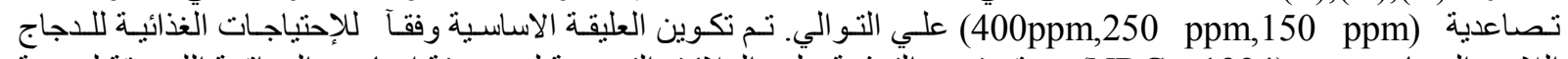

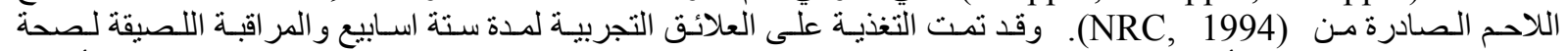

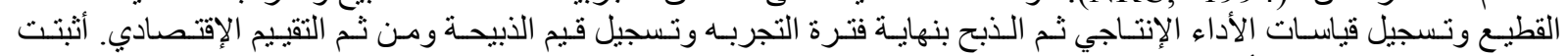

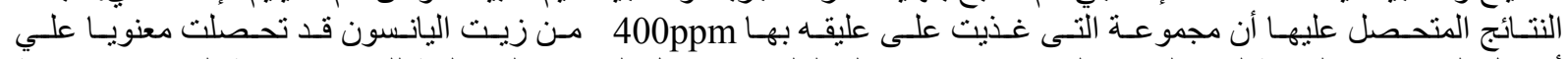

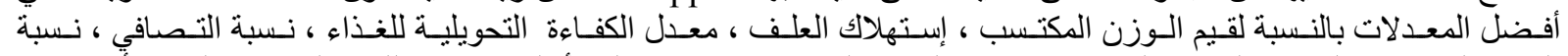

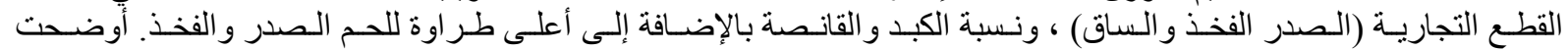

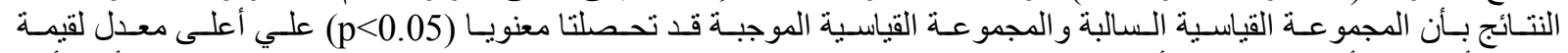

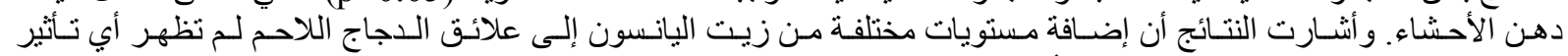

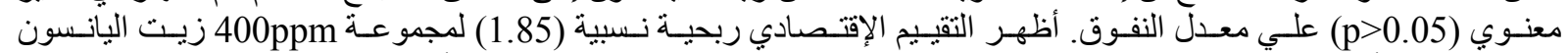

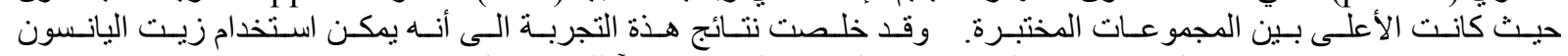

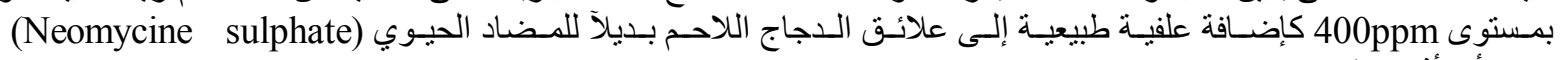
بدون أي أثر ضـار. 